\title{
A Strong Argumentative Orientation Makes the Cognitive Closure Easier: The Case for a Persuasive Health Message
}

\author{
Vincent Coppola ${ }^{1}$, Fabien Girandola ${ }^{2}$, Odile Camus ${ }^{3}$ \\ 1 University of Toulouse 3, LERASS, 115 route de Narbonne, 310177, Toulouse, France \\ 2 University of Aix-Marseille, LPS, 29 avenue Robert Schuman, 13621, Aix-en-Provence, France \\ ${ }^{3}$ University of Rouen, CRFDP, Rue Lavoisier, 76821, Mont Saint Aignan, France
}

The rationale of this study is that scalar adverbs are likely to act as a convenient means to achieve cognitive closure because they stress the argumentative orientation of the message. Based on this assumption, an experiment shows that the introduction of scalar adverbs in the message decreases the extent of its cognitive elaboration and increases its perceived quality and effectiveness for people high in need for closure, but not for people low in need for closure, for whom the outcomes are reversed with regard to perceived quality and persuasiveness of the message. To what extent such outcomes are likely to be affected by some variables traditionally studied in the persuasion literature is addressed in the discussion.

Key words: argumentative orientation, message processing, need for closure, persuasion, health communication

Social psychologists have always been interested in the processes by which human judgments are formed and goal-directed (Kruglanski, 1990; Kruglanski \& Azjen, 1983; Kunda, 1990; for a review, see Molden \& Higgings, 2012). In particular, the "need for closure" concept, originally embedded in the Kruglanski's (1989) lay epistemic theory, has been defined as the "desire for an answer on a given topic, any answer, as compared to confusion and ambiguity" (Webster \& Kruglanski, 1994 , p. 1049). As such, it has been viewed as a motivation to draw a conclusion quickly and terminate cognitive processing related to the issue (Kruglanski, Orehek, Dechesne, \& Pierro, 2010; Roets \& Van Hiel, 2011a).
Furthermore, in the area of pragmatics, argumentation has been approached through the way lexical items give orientations to utterances, and the meaning of a particular utterance has been viewed as the set of all possible argumentative entailments that can be made from it (Malrieu, 1999). In particular, the concept of "argumentative orientation", originally defined as "the type of conclusions suggested to the recipient, the conclusions that the statement offers as one of the discursive aims" (Anscombre \& Ducrot, 1983, p. 149), has been advanced to describe how the introduction of scalar adverbs in a given utterance direct the interlocutor towards a clear-cut conclusion (Moeschler, 2016).

Correspondence concerning this article should be addressed to Vincent Coppola, University of Toulouse 3, LERASS, 115 route de Narbonne, 310177, Toulouse, France. E-mail: vincent.coppola@iut-tarbes.fr ORCID https://orcid.org/0000-0003-0899-6693

Received March 12, 2019 
The current study relies on these two theoretical frameworks, and addresses the question of whether matching the message argumentative orientation to the recipients' need for closure impacts his or her attitude toward the message and, as a consequence, its effectiveness. It is designed as follows. First, a brief overview of the "need for closure" concept is made. It consists in presenting its main theoretical features. Second, the rationale of the study is advanced. Grounded in the framework of integrated pragmatics, it consists in arguing that the message argumentative orientation is a feature likely to be congruent with the need for closure expressed by the recipients, resulting in a more favorable attitude toward the message. Third, a study carried out on university campus in the context of a health promotion intervention is offered as the empirical core in response to the above-mentioned research question.

\section{The Need for Closure: An overview}

Broadly speaking, the need for (non specific) closure has been defined as reflecting the desire for an answer on a given topic, any answer as long as it is clear, definite, and secure, as opposed to the undesirable alternative of ambiguity and confusion (Kruglanski, 1990; Kruglanski \& Webster, 1996). Engaged in an ongoing decision-making process, people may experience an urgent desire to attain a swift and firm decision so that forming a clear-cut opinion or reaching a definite conclusion becomes a goal in itself. In that case, they are willing to promote cognitive activities and/or strategies that best meet their immediate goal in the ongoing decision-making process and, as a result, display a series of cognitive bias well documented in the field of social cognition (Kruglanski \& Freund, 1983; Kruglanski \& Fishman, 2009). Once the closure is attained, people can be reluctant to have their opinion and conclusion challenged, and thus promote cognitive activities in order to maintain it and stick to it, no matter what (Kruglanski, Webster, \& Klem, 1993).
Embedded in the conceptual definition of the need for closure, the urgency tendency and the permanence tendency have been outlined as the two distinct ways whereby the motivation toward cognitive closure exerts its effects (Kruglanski \& Webster, 1996; Roets, Van Hiel, \& Cornelis, 2006). The urgency tendency has been defined as "an individual's inclination to attain closure as soon as possible", whereas the permanence tendency has been defined as "an individual's inclination to maintain it for as long as possible" (Kruglanski \& Webster, 1996 , p. 263). The former promotes behavior in which people seize on early available evidence or information that allows them to decide and conclude without sacrificing their sense of validity; the later may lead to behavior in which people freeze on the reached decision or conclusion and are reluctant to reconsider it (Kruglanski \& Webster, 1996; Roets \& Van Hiel, 2006). As Kunda (1999) argued: "When we are motivated to achieve closure, we may "freeze" our thinking process early on, as soon as we have arrived at what seems like a good enough solution" (p. 242). Defined through the two aforementioned concepts, the need for closure is a typical illustration of a motivational mechanism influencing the extent of efforts and care people invest in information processing aimed at reaching a decision (for reviews of the empirical evidence, see Kruglanski, 2004; Kruglanski \& Chun, 2008; Kruglanski \& Fishman, 2009; Kruglanski \& Webster, 1996; Webster \& Kruglanski, 1998).

Particularly relevant for the current study is the seizing process. When people succumb to the urge to make a decision or reach a conclusion, they are more likely to quickly select and prioritize in their environment the most salient and easily accessible information. They are also more likely to quickly rely on cues presumably in order to supply quick closure, so that the need for closure should finally affect not only the amount but also the type of information processed. Kruglanski \& Webster (1996) argued that: "people under a heightened need for closure may seize on information appearing early in a sequence [and] should base their judgments predominantly 
on early or preexisting cues" (p. 265) and also argued for a "speeded-up reliance on early cues implied by seizing" (p. 268). Similarly, Sankaran, Szumowska and Kossowska (2017) argued that "given a choice, individuals high in need for closure would choose the effortless, i.e., easiest and quickest, way to attain closure" (p. 309).

Numerous studies have confirmed the tendency of individuals under a heightened need for closure to select peripheral cues as a quick and easy route to closure. For instance, in a research dealing with persuasion, Klein \& Webster (2000, Study 1) showed that attitudes of individuals high in dispositional need for closure were more affected by the number of arguments (i.e., "the message-length heuristic") than by argument quality, whereas low need for closure individuals were more likely to be influenced by the quality of the arguments (i.e., systematic processing). Particularly interesting in the Klein and Webster's (2000) research was the fact that individuals high in dispositional need for closure processed a message systematically if a heuristic cue was unavailable to provide an easy means for closure (Study 2). In a study dealing with consumer information processing and purchase decisions, Cronley, Posavac, Meyer, Kardes, and Kellaris (2005) showed that the degree to which price was perceived to predict quality (i.e., "the price-quality heuristic") was overestimated when consumers' need for cognitive closure was high. Similarly, Vermeir, Van Kehnove, and Hendrickx (2002) showed that dispositional high need for closure consumers generally demonstrated a higher search effort for price and promotional information, which are supposed to be heuristic decision cues in the shopping context (see also Vermeir \& Van Kehnove, 2005). Using a knowledge task, Wesson and Pulford (2005) showed that individuals high in dispositional need for closure used to a greater extent the speaker's confidence cue, when making choices, and concluded that the use of this "confidence heuristic" could satiate their desire to make quick decisions and confident choices.
This idea that "the higher the magnitude of their need for closure [...] the greater their tendency to rely on simple judgmental heuristics" (Pierro, Manetti, Erb, Spiegel, \& Kruglanski, 2005 , p. 103) is one of the most important implications of the research on need for cognitive closure. And this is of critical importance for the rationale of this study, insofar as it will be now addressed whether scalar adverbs are likely to act as judgmentally relevant cues, on which people could seize when they process an informational message under a heightened need for closure.

\section{Scalar Adverbs as Argumentative Markers: An Easy-Way Out Option?}

In the area of pragmatics, it has been largely argued that the meaning of words conditions the dynamics of discourse and a single fact can be understood in different ways according to its linguistic formulation (Portolés \& Yates, 2014). This direction has been explicitly and exhaustively taken in the Anscombre and Ducrot's (1983) "Theory of Argumentation within Language", with the purpose to show that language itself is argumentative, both at the level of the basic sentence and individual words themselves. This theory supported the concept that the meaning of utterances can be captured in terms of the conclusions for which they can be used as arguments and the argumentative function of language should be seen as primary, compared to its informative and descriptive function (Anscombre \& Ducrot, 1976; Ducrot, 1993; Iten, 2000). For this reason, the Anscombre and Ducrot's (1983) theory of argumentation has been judged as a "radically ascriptivist" approach of semantics (Rocci, 2017, p. 124).

Anscombre and Ducrot's approach emanates from their interest in describing how words such as "almost, only, even, already, more than, near from, at least, no less than", work as argumentative operators, in that they direct the interlocutor for the recovering of the "argumentative orientation" (also called "argumentative force") of the utterances in which they occur (Van Eemeren, 2001; Van Eemeren, 
Grootendorst, \& Snoeck Henkemans, 1996). The argumentative orientation can be thought of as the set of inferences that can be drawn from a given utterance and it has been largely claimed that it can be stimulated by the words referred to above, called "scalar adverbs" (Bassano, 1991; Champaud \& Bassano, 1987; Defrise \& Nirenburg, 1990; Mc Keown \& Elhadad, 1991). Scholars have described the role of these word cues as adding constraints on the argumentative orientation of the sentences they modify (Henning, 1982; Kay, 1990; Sadock, 1981). In particular, Anscombre and Ducrot (1983) argued that "the presence of some morphemes (nearly for instance) in some sentences gives an intrinsic argumentative orientation to these sentences, predisposing them to be used in some types of conclusions rather than others" (p. 149).

In this "meaning is orienting" view of language fiercely supported in the radical argumentativism approach, scalar adverbs are conceptualized as adding a guidance function to utterances and as such encoding "instructions" (i.e., procedural content) rather than "concepts" (descriptive content) ${ }^{1}$. As Verhagen (2008) argued:

"an addressee takes an utterance not (just) as an instruction to construe an object of conceptualization in a particular way, but (also) as an instruction to engage in a reasoning process, and to draw certain conclusions; it is typically [...] understanding what the speaker/ writer is getting at (what he wants you to infer), that counts as successful communication" ( $p$. 316).

The current study aims at exploring the guidance function that scalar adverbs can have in the processing of an informational message about a disease presented as a new emerging sexually transmitted infection. It was reasoned that when people are processing a health message about an unfamiliar disease with the aim to form an opinion about its se-

\footnotetext{
1 For the distinction between "conceptual content" and "procedural content", see also Deirdre Wilson (2011).
}

verity, the introduction of scalar adverbs in the message was supposed to serve the seizing process and the urgency tendency, intrinsically related to a high need for cognitive closure. For instance, an utterance such as "2400 people have already contracted the virus just for the period from January to June" was supposed to guide the recipients about the (perceived) seriousness of the disease, more than the same utterance without "already" and "just". Similarly, an utterance such as "Since the outbreak of the disease three years ago, up to 6000 new persons have contracted the virus each year" was supposed to have the same guidance function, more than the same utterance without "up to". Said differently, the addition of scalar adverbs in the message was expected to be a convenient means to attain closure, and as such, of a greater relevance for people high in need for closure, who are supposed to seize quickly on an early available solution (i.e., "speeded-up reliance on early cue phenomena”, Kruglanski \& Webster, 1996, p. 268), than for people low in need for closure, who are engaged in a more extensive information search before deciding on the issue. In relation with this reasoning were the following hypotheses: "People with high need for cognitive closure will process the message containing scalar adverbs more superficially $(\mathrm{H} 1)$ rate it better with regard to its quality $(\mathrm{H} 2)$, and judge it more convincing $(\mathrm{H} 3)$ than people with lower need for cognitive closure".

\section{Method}

\section{Participants}

Participants were undergraduate students aged 18 to 23 years old attending in a management and accountability course at a large public University in the south of France. They were invited to participate in a health promotion intervention about a sexually transmitted infection. Upon arrival to the session, student volunteers were told that participation in the study entailed reading a fact sheet about the "Paramyxoviridae infection" and then complet- 
ing a questionnaire. They were told that this fact sheet had been designed by the Health Promotion Department with the purpose of informing them about this new and emerging disease and enabling them to assess its severity. To make sure participants were unfa- miliar with the "Paramyxoviridae infection", they were asked to answer the following questions: "Do you know of the Paramyxoviridae infection?", and "Did someone in your environment inform you about the Paramyxoviridae infection?"

Table 1 Sample manipulations in each of two versions of the epidemiological report

Non-scalar argumentation
- Since the outbreak of the disease three
years ago, 6000 new persons have
contracted the virus each year.
- The virus has contaminated 1238 persons
the last year throughout Europe.

- 250 infections have been registered in our country, of which 180 from January to June.

- 50 new cases occurred during the last six months for the people aged from 18 to 25 years old. Considering those who do not know they are positive, this number is higher than 50.

- As for other sexually transmitted infections, people can expose themselves during a single act of unprotected intercourse and it is now anticipated that 1500 sexually active young adults will catch the virus within the next two years.

- Many people will get sick and twenty percent of those who develop symptoms will die.

- By contracting this new virus, they will develop brain damage and suffer from breathing difficulties.

- Because younger adults are especially susceptible, university communities are at risk for widespread viral outbreaks.

- According to Professor Schwartz, from the National Student Health Center, one out of four students will exhibit the most serious form of the Paramyxoviridae infection in a near future.

- It is estimated that a vaccine will not be found until the next 5 years, so the adoption of safer sex practices nowadays is the only way to protect yourself.
- Since the outbreak of the disease three years ago, up to 6000 new persons have contracted the virus each year.

- The virus has contaminated no less than 1238 persons the last year throughout Europe.

- Already 250 infections have been registered in our country, of which 180 just for January to June.

- Almost 50 new cases occurred during the last six months for the people aged from 18 to 25 years old, and even more than 50 when it is considered those who do not know they are positive.

- As for other sexually transmitted infections, people can expose themselves during a single act of unprotected intercourse and it is now anticipated that not less than 1500 sexually active young adults will catch the virus within the next two years.

- Many people will get sick and twenty percent of those who develop symptoms will die.

- By contracting this new virus, they will develop brain damage and suffer from breathing difficulties.

- Because younger adults are especially susceptible, university communities are at risk for widespread viral outbreaks.

- According to Professor Schwartz, from the National Student Health Center, almost one out of four students will exhibit the most serious form of the Paramyxoviridae infection in a near future.

- It is estimated that a vaccine will not be found until the next 5 years, so the adoption of safer sex practices nowadays is the only way to protect yourself. 


\section{Independent Variables}

The current study was implemented in the context of a health promotion intervention on university campus. A fictitious sexually transmitted infection referred to as the "Paramyxoviridae infection" served as the main topic in this study and was presented as an emergent disease. The first experimental manipulation consisted in varying the scalar argumentation in a text presented as an epidemiological report about the "paramyxoviridae infection". In one version, scalar adverbs were incorporated in some of statements so it was referred to as the "scalar argumentation version", while in another version, no scalar adverbs were included so it was referred to as the "non-scalar argumentation version". Both versions were prepared with the concern of maintaining them as identical as possible in terms of length (scalar $=234$ vs. non scalars $=220$ ), sentence structure, and content. Sample manipulations are provided in Table 1.

The need for closure was the other relevant factor. In this study, the need for closure was treated as an individual-difference variable (i.e., dispositional need for closure), and measured with the Roets and Van Hiel's (2011b) abridged

\footnotetext{
2 Though need for closure may vary as a function of the situation, the possibility that it could be a dimension of stable individual differences has been largely explored in the past research, giving rise to the Need for Closure Scale (Webster \& Kruglanski, 1994). High scorers on the Need for Closure Scale are supposed to make judgments in a flash, feel intrinsically motivated to obtain answers, conclusion and decision as swiftly as possible, being in the quest for a fast and efficient processing of information whenever possible. On the contrary, low scorers on the Need for Closure Scale are supposed to ponder excessively and postpone their judgment as long as possible, engaging in a more enduring search for information and effortful processing. In this study, the use of the Roets and Van Hiel's (2011) abridged version was driven by practical considerations, since the completion of the NFCS was only one part of the procedure.
}

version of the Need For Closure Scale, initially developed by Webster and Kruglanski (1994)2. This scale consists of 15 items (e.g., "I dislike questions which could be answered in many different ways", "I don't like situations that are uncertain"), all loaded on one dimension, each of them being rated on 6-point Likert scales ranging from 1 (completely disagree) to 6 (completely agree) with higher scores indicating a greater (dispositional) need for closure. So, based on the scores obtained with this short version of the need for closure scale, it was possible to classify subjects as "high in need for closure" vs. "low in need for closure".

\section{Dependent Variables}

The information processing. A thought-listing task was used to assess how much the message was cognitively processed. Participants were provided with a paper sheet with 10 boxes and instructed as follows:

We are now interested in what you were thinking about as you were reading the message. Simply write down the first thought and idea that came to your mind in the first box, the second idea in the second, etc. Please put only one idea or thought in a box. You should try to record only those ideas that you were thinking while you were reading the message. You will have 3 minutes to write down all these thoughts and ideas. Please be completely honest and list all of the thoughts that you had (adapted from Petty \& Cacioppo, 1977, p. 648).

Two coders, blind to the experimental hypotheses, were asked to evaluate whether these collected thoughts were message content and topic - relevant elaborations ("Young adults like me are highly susceptible to this infection", "This new disease seems to be serious", I will continue to use a condom", "It is not a risk as long as condom is used", "I am not concerned because I am mono-partner", etc.), or not ("It looks like an exam", "I am happy to take part in this questionnaire", "I need to smoke a cigarette", etc.). Intercoder agreement was on $88 \%$ of the listed thoughts, and discussions between coders and the experimenter took place to resolve any disagree- 
ments. An index of the amount of relevant thought in which recipients engaged when exposed to the experimental message was created by summing the total number of message content - topic - relevant cognitions.

The extensiveness of the processing of the issue - relevant information was also measured through the memorization of specific pieces of information delivered in the message. Participants were faced with four multiple-choice questions, each of them offering four alternative responses. They were asked to select which of the four options tallied with the message content and received a score from 0 to 4 , which was used as the index of their cognitive investment in the processing of the message ${ }^{3}$.

The perceived quality of the message. Three dimensions were assessed and treated separately in the subsequent analyses: clarity, cognitive challenge, and relevance. With regard to clarity and cognitive challenge dimensions, items were adapted from the "Perceived Message Cognition Value Scale" (Lane, Harrington, Donohew, \& Zimmerman, 2006). Participants were asked to indicate on a scale from 1 "no, not at all" to 7 "yes, absolutely" how "understandable", "comprehensible", and "clear" the message was. Participants' responses to these three Likert-type scale items were averaged to obtain a general index of the perception of the intelligibility of the message (Cronbach's $\alpha=.94$ ). Participants also indicated on a scale from 1 "no, not at all" to 7 "yes, absolutely" how "intellectually interesting", "intellectually appealing", and "thought provoking" the message was. Participants' responses to these three Likert-type scale items were averaged to obtain a general index of the perception of how much cognitively stimulat-

${ }^{3}$ Although the "cognitive response approach" has been historically preferred to a "memorization task" to assess the degree of cognitive elaboration, in a large number of studies, memory performance has been used to measure how deeply the message content was processed (Cacioppo, Petty, \& Morris, 1983; Peltier \& Schibrowsky, 1994; Petty \& Cacioppo, 1979). ing the message was (Cronbach's $\alpha=.92$ ). For the relevance dimension, participants indicated on a scale from 1 "no, not at all" to 7 "yes, absolutely" how "useful", "worthwhile" the message was, and to what extent "they would recommend that this message be published in the campus magazine". Again, a general index of the perceived relevance was calculated by averaging participants' responses to these items (Cronbach's $\alpha=.95$ ).

The persuasiveness of the message. Participants were asked to indicate on the same 7-point Likert type scale "how likely they could make changes in their sexual behavior (i.e., safer sex) based on the message they read", and "how the message they read made them thinking to be more cautious with regard to their sexual practices". These two items were combined into a single overall measure of message persuasiveness ( $r=.83$ / Cronbach's $\alpha=.91)$

\section{Procedure}

The study was conducted in the classroom where students usually received classes in groups of 25 to 30 people. At the beginning of the experimental session, participants were told that the "Preventive Medicine and Health Promotion Department" was implementing an information program for students that consisted in informing them about some "emerging" infectious diseases. They were told that the participation in the session entailed reading a fact sheet, which had been designed in order to make the students aware of an unfamiliar disease and able to rate its gravity. It was clarified that they were expected to make a decision about the severity of the disease and report it at the end of the session. This was used as a pretext to induce and make the focus on what the closure was about regarding the ongoing session. Furthermore, they were told that it was necessary to collect their opinions and judgments by means of an anonymous questionnaire in order to prepare a group discussion scheduled at the end of the session. They were also informed that the "Preventive Medicine and Health Promotion 
Department" intended to circulate the fact sheet on campus, and therefore, needed to collect their judgments on its clarity, appeal and strength. All this introductory speech served to justify the study.

Participants received two distinct booklets. The first one contained the informational message stimulus (i.e., the fictitious epidemiological report). It began with a short presentation of the "Preventive Medicine and Health Promotion Department" (purposes, phone numbers, staff, hours of duty office and other diverse information) and then referred to the topic. Under the following heading: "Paramyxoviridae infection: Let us take stock of the situation" was delivered the message stimulus, which focused on the prevalence and incidence of the disease and harbored the linguistic manipulation.

The second booklet included the Need for Closure Scale and items relative to the dependent measures. The filling in of the Need for Closure questionnaire was presented as training for the filling in of the rest of the booklet. In particular, the participants were made to believe that it was necessary to start by completing the Need for Closure questionnaire in order to get used to these data collection methods and thus make sure that they correctly complete the rest of the questionnaire (i.e., dependent measures). So, one hundred sixty two students completed the Roets and Van Hiel's (2011b) Need for Closure Scale. Re- spondents' composite scores were calculated by summing across each of the individual items and, as for previous research, a tertiary split was used to categorize high and low need for closure respondents. Participants scoring in the upper third of the distribution (total score $>64$ ) were identified as the "high need for closure" group ( $n=53$ ) while participants scoring in the lower third of the distribution (total score $<41$ ) were labelled as the "low need for closure" group ( $n=54)$.

In sum, one hundred and seven subjects participated in the study resting on a $2 \times 2$ between-subjects factorial design with two degrees of dispositional need for closure (high vs. low), orthogonally crossed with the two scalar argumentation conditions (scalar argumentation vs. non-scalar argumentation). No time constraint was imposed while participants read the first booklet, completed the NFCS and the dependent variables booklet. Finally, they were thanked and dismissed after they were told about the true objectives of the study.

\section{Results}

\section{The Information Processing (see Table 2)}

The first hypothesis stated that the presence of scalar adverbs would have the effect of reducing the information processing, especially for people with higher need for cognitive closure. The hypothesis was sustained by a need

Table 2 Means $(M)$ and Standard Deviation (SD) for the extent of message information processing as a function of the scalar argumentation and the dispositional need for closure

\begin{tabular}{lcccc}
\hline & \multicolumn{2}{c}{ Low Need for Closure } & \multicolumn{2}{c}{ High Need for Closure } \\
\cline { 2 - 5 } & $\begin{array}{c}\text { Non Scalar } \\
\text { Argumentation } \\
n=26\end{array}$ & $\begin{array}{c}\text { Scalar } \\
\text { Argumentation } \\
n=28\end{array}$ & $\begin{array}{c}\text { Non Scalar } \\
\text { Argumentation } \\
n=25\end{array}$ & $\begin{array}{c}\text { Scalar } \\
\text { Argumentation } \\
n=28\end{array}$ \\
\hline $\begin{array}{l}\text { Number of message } \\
\text { content - topic - }\end{array}$ & $M=2.11$ & $M=2.25$ & $M=1.76$ & $M=1.25$ \\
related thoughts & $(S D=.82)$ & $(S D=.75)$ & $(S D=.83)$ & $(S D=.70)$ \\
$\begin{array}{l}\text { Score of } \\
\text { memorization }\end{array}$ & $M=2.19$ & $M=2.11$ & $M=1.68$ & $M=1.03$ \\
\hline
\end{tabular}

Note. The lower the mean, the lower the number of thoughts, and the lower the score of memorization. 
for closure $x$ scalar argumentation interaction effect on the number of message content topic - relevant cognitions $(F[1,103)=4.63$, $\left.p=.034, \eta^{2}=0.04\right)$. As illustrated by Figure 1 , a detailed analysis revealed that the number of cognitions was lower in the scalar argumentation condition than in the non-scalar argumentation condition for participants with high need for cognitive closure $\left(M_{\text {scalar }}=1.25\right.$ vs. $M_{\text {non-scalar }}=1.76, F[1,103]=5.73, p=.018, \eta^{2}=$ $0.05)$, but not for participants with low need for cognitive closure $\left(M_{\text {scalar }}=2.25\right.$ vs. $M_{\text {non-scalar }}=$ $2.11, F<1)$. The same need for closure $\mathrm{x}$ scalar argumentation interaction effect on the score of memorization was scrutinized. Even though it failed to reach conventional significance $\left(F[1,103]=2.86, p=.094, \eta^{2}=0.027\right)$, planned comparisons revealed that the score was significantly lower in the scalar argumen- tation condition than in the non-scalar argumentation condition for participants with high need for closure $\left(M_{\text {scalar }}=1.03\right.$ vs. $M$ $\left.1.68, F[1,103]=7.52, p=.007, \eta^{2}=0.068\right)$, but not for their low need for closure counterparts $\left(M_{\text {scalar }}=2.11\right.$ vs. $\left.M_{\text {non-scalar }}=2.19, F<1\right)$, (see Figure 2).

The Perceived Quality of the Message (see Table 3)

The second hypothesis stated that the presence of scalar adverbs would have the effect of leading to a better appreciation of the message, especially for people with higher need for cognitive closure. The hypothesis was sustained by a need for closure $x$ scalar argumentation interaction effects on perceived clarity $\left(F[1,103]=4.45, p=.037, \eta^{2}=0.041\right)$. As illus-

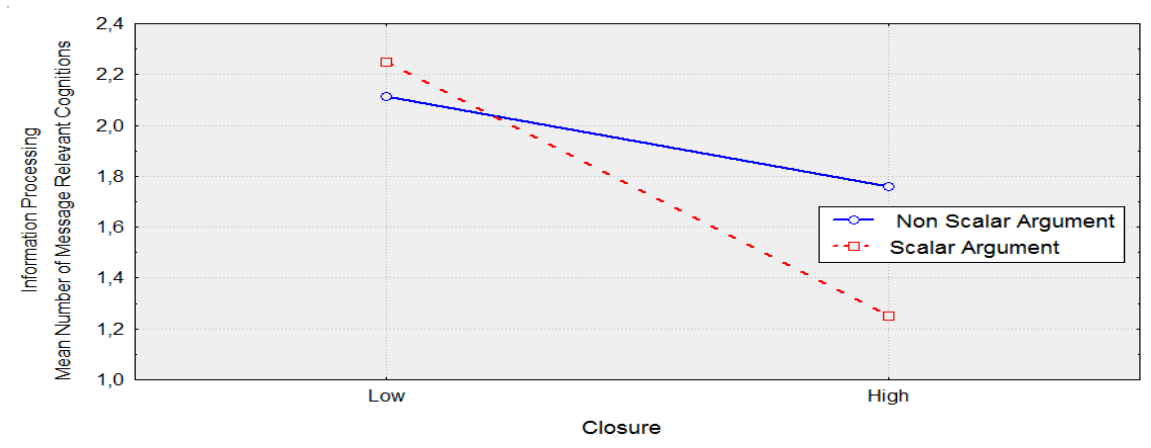

Figure 1 Need for closure $\mathrm{x}$ scalar argumentation interaction on information processing

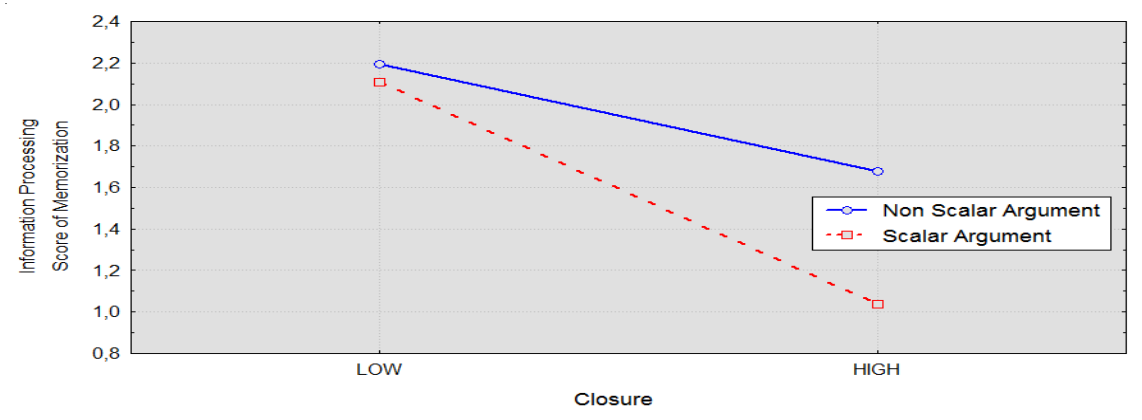

Figure 2 Need for closure $\mathrm{x}$ scalar argumentation interaction on memorization 
trated by Figure 3 , the version with scalar adverbs was considered clearer than the version without scalar adverbs for participants high in need for closure $\left(M_{\text {scalar }}=5.12 \mathrm{vs}\right.$. $M_{\text {non-scalar }}=4.45, F[1,103]=6.70, p=.011, \eta^{2}=$ 0.06 ), but not for participants low in dispositional need for closure $\left(M_{\text {scalar }}=4.61 \mathrm{vs}\right.$. $\left.M_{\text {non-scalar }}=4.70, F<1\right)$. A same interaction effect emerged with regard to how the message was appealing $(F[1,103]=17.34, p<.0001$, $\left.\eta^{2}=0.144\right)$. The version with scalar adverbs was judged as more appealing than the version without scalar adverbs by participants high in need for closure $(M$ $=4.85$ vs. $M$ 4.08, $\left.F[1,103]=8.06, p=.005, \eta^{2}=0.072\right)$, but less appealing by participants with low need for closure $\left(M_{\text {scalar }}=3.57\right.$ vs. $M_{\text {non scalar }}=4.40$, $\left.F[1,103]=9.31, p=.003, \eta^{2}=0.083\right)$, (see Figure 4). The same pattern of results emerged with regard to the perceived relevance of the message. As shown by Figure 5, a significant interaction effect emerged $(F[1,103]=13.83$, $\left.p<.0003, \eta^{2}=0.118\right)$ and revealed that the scalar version was considered more relevant than the version without scalar adverbs for participants with high need for closure $\left(M_{\text {scalar }}=\right.$

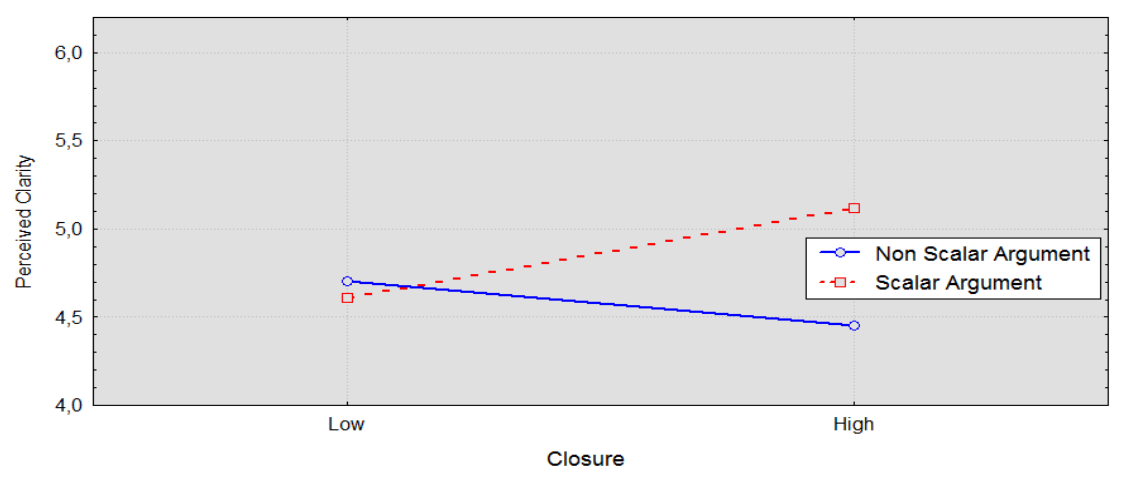

Figure 3 Need for closure $\mathrm{x}$ scalar argumentation interaction on perceived clarity

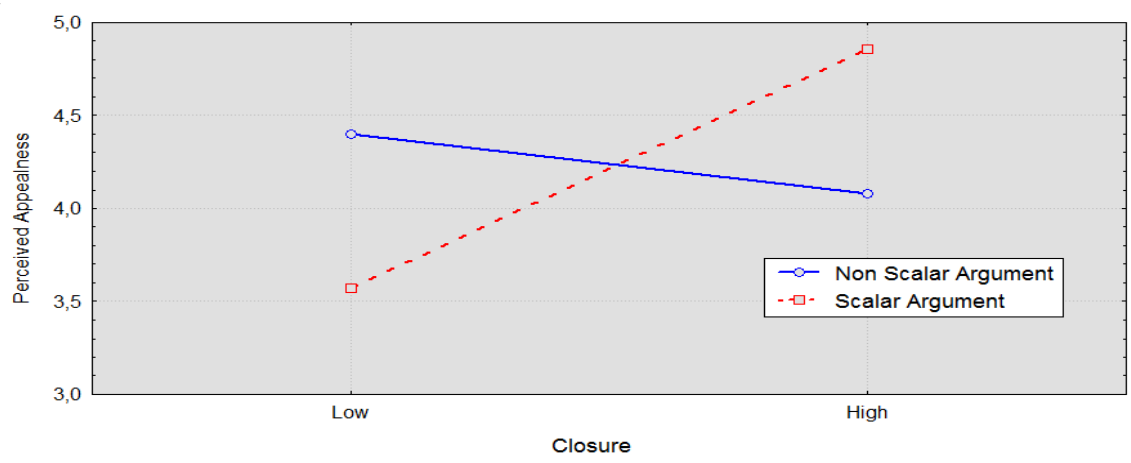

Figure 4 Need for closure $\mathrm{x}$ scalar argumentation interaction on perceived appealness 


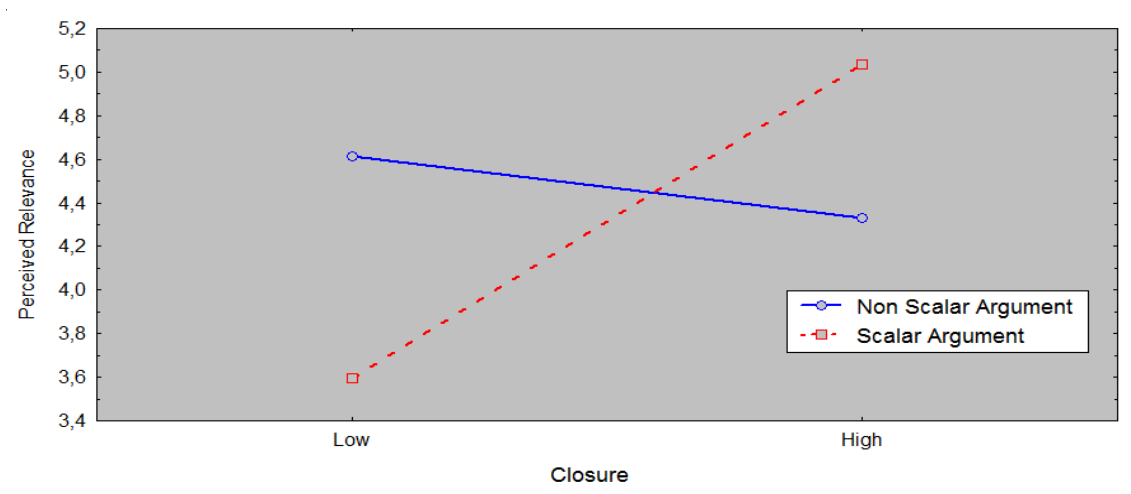

Figure 5 Need for closure $\mathrm{x}$ scalar argumentation interaction on perceived relevance

Table 3 Means (M) and Standard Deviation (SD) for the perceived quality and the persuasiveness of the message as a function of the scalar argumentation and the dispositional need for closure

\begin{tabular}{lcccc}
\hline & \multicolumn{2}{c}{ Low Need for Closure } & \multicolumn{2}{c}{ High Need for Closure } \\
\cline { 2 - 5 } & $\begin{array}{c}\text { Non Scalar } \\
\text { Argumentation } \\
n=26\end{array}$ & $\begin{array}{c}\text { Scalar } \\
\text { Argumentation } \\
n=28\end{array}$ & $\begin{array}{c}\text { Non Scalar } \\
\text { Argumentation } \\
n=25\end{array}$ & $\begin{array}{c}\text { Scalar } \\
\text { Argumentation } \\
n=28\end{array}$ \\
\hline Clarity & $M=4.70$ & $M=4.61$ & $M=4.45$ & $M=5.12$ \\
dimension & $(S D=.92)$ & $(S D=.69)$ & $(S D=.88)$ & $(S D=1.17)$ \\
Cognitive challenge & $M=4.40$ & $M=3.57$ & $M=4.08$ & $M=4.85$ \\
dimension & $(S D=.95)$ & $(S D=.74)$ & $(S D=1.02)$ & $(S D=1.21)$ \\
Relevance & $M=4.61$ & $M=3.59$ & $M=4.33$ & $M=5.03$ \\
dimension & $(S D=1.18)$ & $(S D=1.07)$ & $(S D=1.29)$ & $(S D=1.24)$ \\
Persuasiveness & $M=3.98$ & $M=2.91$ & $M=3.50$ & $M=3.98$ \\
& $(S D=.98)$ & $(S D=.90)$ & $(S D=1.10)$ & $(S D=1.05)$ \\
\hline
\end{tabular}

Note. The higher the mean, the more the message is perceived as clear, intellectually appealing, and relevant and the higher the persuasiveness of the message.

5.03 vs. $M_{\text {non-scalar }}=4.33, F[1,103]=4.55, p<$ $\left..04, \eta^{2}=0.042\right)$, but the contrary was revealed for participants with low need for closure $(M$ scalar $=3.59$ vs. $M_{\text {non-scalar }}=4.61, F[1,103]=9.80$, $\left.p<.001, \eta^{2}=0.087\right)$.

\section{The Persuasiveness of the Message (see} Table 3)

The third hypothesis stated that the presence of scalar adverbs would have the effect of enhancing the persuasiveness of the message, especially for people with higher need for cog- nitive closure. As in the case of the previous hypotheses, this prediction was sustained by an interaction effect $(F[1,103]=15.37, p=$ $.00016, \eta^{2}=0.13$ ). The likelihood of safer sex practices in response to the fact sheet was higher in the scalar argumentation condition than in the non-scalar argumentation condition for participants with high cognitive closure $\left(M_{\text {scalar }}=3.98\right.$ vs. $M_{\text {non-scalar }}=3.50, F[1,103]=$ $2.79, p=.09, \eta^{2}=0.026$ ), but lower for participants with low need for closure $\left(M_{\text {scalar }}=2.92\right.$ vs. $M_{\text {non-scalar }}=3.98, F[1,103]=15.11^{\text {scalar }} p=.001$, $\eta^{2}=0.128$ ), (see Figure 6). 


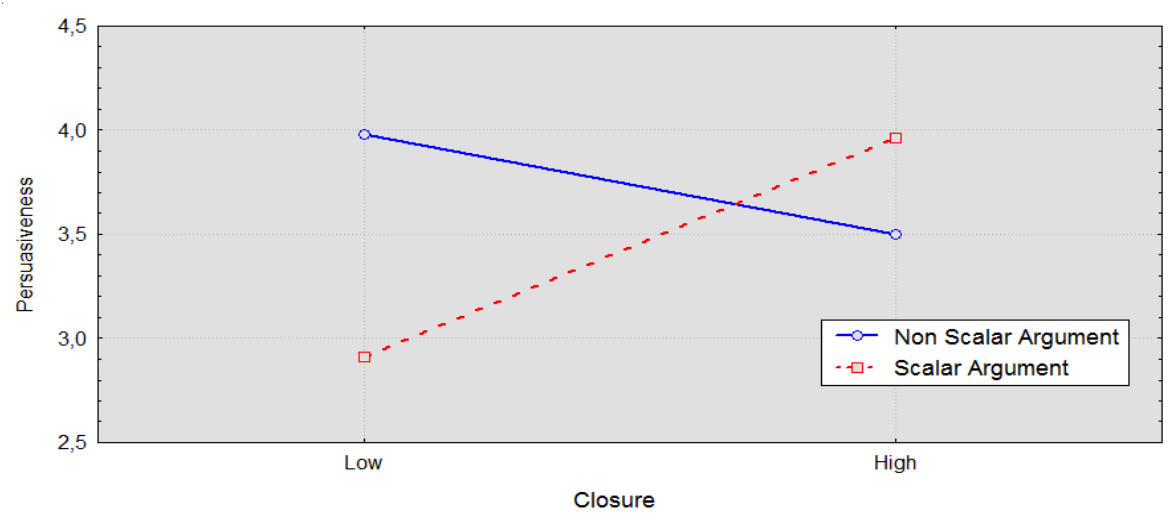

Figure 6 Need for closure $\mathrm{x}$ scalar argumentation interaction on persuasiveness

\section{Discussion}

\section{Matching Health Messages to the Informa- tion-processing Style}

The three hypotheses outlined in the introduction were sustained by the results. With regard to the information processing, the number of relevant cognitions as well as the score of memorization associated with the message content was lower in the scalar argumentation condition than in the non-scalar argumentation condition for participants with high cognitive closure, but not for participants with low cognitive closure. Regarding the judgments on the message, the content was perceived as clearer in the scalar argumentation condition than in the non-scalar argumentation condition, only for participants with high cognitive closure. The message content was perceived as more intellectually stimulating in the scalar argumentation condition than in the non-scalar argumentation condition for participants high in need for closure, whereas it was the contrary for the participants with low cognitive closure. The same pattern of results emerged with regard to the judgments on the relevance of the message. In regards to message effectiveness, behavioral intentions reported by participants with high cognitive closure were higher in the scalar argumentation condition compared to the non-scalar argumentation version, but for participants with low cognitive closure, the reverse effect was observed.

In line with the theoretical framework outlined in the introduction of the study, a matching versus mismatching perspective was privileged for explaining interaction effects that emerged from the analyses. It was reasoned that the accentuation of the argumentative orientation by means of scalar adverbs matched the cognitive style of people with high need for closure, but mismatched that of people with low need for closure. Furthermore, it was assumed that participants would be able to perceive the extent to which the message was congruent with their need for closure, and as a result, would evaluate the latter in accordance with this perceived congruency. In the area of health communication, it has been largely evidenced that matching the message to the individuals' needs and information-processing styles is a relevant technique to enhance persuasion and behavioral intentions (WilliamsPiehota, Schneider, Pizzaro, Mowad, \& Salovey, 
$2003)^{4}$. In addition, it has been showed that this matching effect in persuasion was mediated by subjective perceptions of the message quality (Lavine \& Snyder, 1996; Quintiliani \& Carbone, 2005).

\section{Future Directions of Research}

Another process could be advanced for explaining these interaction effects, in particular, why for participants with low cognitive closure, the introduction of scalar adverbs produced reverse effects on judgments about the appeal and relevance of the message as well as its persuasiveness. It could also be reasoned that, by stressing the argumentative orientation of the message, such an adverbial marking could be perceived as constraining the judgment and decision, and thus, violating the desire to avoid cognitive closure. As a result, this sense of violation could trigger an aversive reaction whose underlying process has to do with psychological reactance. In contrast, such an aversive response would not occur in participants with high need for cognitive closure because the adverbial marking would be a relevant means of attaining quick closure and satisfying their cognitive impatience. This new assumption could be elucidated in future research in which reactance proneness would be assessed as an additional factor (Dillard \& Shen, 2005; Quick \& Stephenson, 2008; Ungar, Sieverding, Schweizer, \& Stadnitski, 2015).

Given that the current study was conducted with an emerging infectious disease (STI) as

${ }^{4}$ This "congruency hypothesis" or "matching effect" has been largely evidenced for a set of individual dispositional needs and/or information-processing styles, such as need for cognition (William-Piehota, Schneider, Pizzaro, Mowad, \& Salovey, 2003), sensation seeking (Donohew, Pugzles Lorch, \& Palmgreen, 1998; Hull \& Hong, 2016), approach/avoidance orientation (Mann, Sherman, \& Updegraff, 2004; Updegraff, Sherman, Luyster, \& Mann, 2007), need for affect vs. cognition (Quintiliani \& Carbone, 2005), regulatory focus (Latimer, William-Piehota, Katulak, Cox, Mowad, Higgins, \& Salovey, 2008), and coping style (William-Piehota, Pizzaro, Schneider, Mowad, \& Salovey, 2005). covert topic, it also raises the question of whether the pattern of results with regard to information processing would be the same if the health topic referred to in the message was a disease for which they have pre-existing and well-established knowledge. It could be assumed that by enhancing the recipient's familiarity with the topic, his or her initial confidence with regard to his or her judgements would be increased, and this sense of confidence could act as a moderating factor. For instance, in the Kruglanski, Peri, and Zakai's (1991) study, the typical finding that under a high need for closure, people exhibit a weaker information seeking tendency than under a low need for closure, was replicated only in a high confidence condition, but eliminated in a low confidence condition. Similarly, in the Strojny, Kossowska, and Strojny's (2016) study, participants high in need for closure tended less to seek information than those low in need for closure, but only when they were supplied with complete information needed to form the required judgments and supposed to enhance their degree of confidence. In the area of consumer decision, it has also been shown that people with a high need for closure were looking for less information, provided that they were familiar with the product and had a preconceived opinion about it (Houghton \& Grewald, 2000; Veirmer, Van Kenhove, \& Hendrickx, 2002). So, supposing that the more familiar the disease, the more the receiver's confidence, one can ask whether the effects outlined in this study regarding the information processing could be magnified if the disease referred to in the message was more familiar to the participants ${ }^{5}$.

\footnotetext{
${ }^{5}$ Maybe the operationalization of this new factor could consist in a "Paramyxoviridae versus HIV/ AIDS" variation, supposing that HIVIAIDS infection is a much more familiar disease of which participants have relevant prior knowledge. Another way to operationalize this factor could consist in asking the participants to answer a questionnaire supposed to assess their knowledge about a given disease (for instance HIVIAIDS) and supplying them with a fictitious score (low vs. high), supposed to reflect their global performance.
} 
Whether the outcomes with regard to the information processing are due to the choice of a particular topic also arises in light of research on the ability to achieve closure (Bar-Tal, Kishon-Rabin, \& Tabak, 1997; Kossowska \& Bar-Tall, 2013). Scholars have developed the idea that, even when people feel the need to finalize their decision and achieve cognitive closure, they may not feel that they are capable of doing so, particularly when the topic in question is highly complex (Roets \& Van Hiel, 2007). It could be assumed that the extent of the receiver's relevant prior knowledge about the ongoing topic regulates his or her perceived ability to make judgments and decisions with confidence and certainty. So, once again, supposing that the more extensive such a knowledge, the more the sense of being able to make up one's mind, it could be investigated whether for people high in dispositional need for closure, the decreased information processing encouraged by the adverbial high marking would be magnified if the referred topic in the message was a disease for which prior knowledge is available.

Another interesting thread in the discussion rests on the idea that the linguistic items investigated in this study could have played a role precisely in the participants' ability to achieve closure. Considering that participants were faced with a health topic that they were unfamiliar with, it could be supposed that they initially perceived themselves as unable to achieve a cognitive closure. From here, it could also be supposed that, because they stress the argumentative orientation of the message, these linguistic items could enhance the ability to achieve cognitive closure, especially for people high in dispositional need for closure, increasing in them the feeling that they are able to form a confident and certain judgment. This could explain why the typical reduction of information processing within participants high in need for closure, compared to their low need for closure counterparts, was further accentuated by the adverbial high marking in the message. Future research should investigate the role of these linguistic items in the recipient's ability to achieve cognitive closure, especially when he or she is faced with complex topics. Furthermore, such research could take physicians as the experimental population, since "premature closure" has been recognized as one among the most common causes of diagnostic error in medicine (Croskerry, 2003; Dhaliwal, 2016; Graber, Franklin, \& Gordon, 2005; Trowbridge, 2008).

\section{Practical Implications of the Study}

Given its implementation in the context of a health promotion intervention, this study could be used by prevention planners as a useful tool to ensure that messages contain linguistic features that appeal to target audiences high vs. low in dispositional need for closure, especially when the message refers to an emergent and unfamiliar sexually transmitted infection. However, the practical implications for health communication require that the matching effect evidenced for the persuasive outcomes be also registered for the behavioral aspects. Although the use of scalar adverbs seems to be a relevant strategy, when the message is directed towards people high in dispositional need for closure, the fact remains that the most important in the matter is to make sure that these intentions and attitudes be expressed in actual and concrete behaviors. According to the ELM of persuasion, the more effortful the processing of the relevant information contained in the message, the more stable, resistant and predictive for action the attitude which results from it (Petty \& Cacioppo, 1986; Petty, Haugtvedt, \& Smith, 1995). Now, it should be reminded that the extent of processing (i.e., cognitive elaboration) was impaired by the adverbial high marking for participants high in need for closure. In consequence, one can wonder to what extent the effect on preventive intentions yielded by this linguistic manipulation may lead to effective and lasting behavior, especially for individuals high in need for closure. In a current epidemiological context characterized by the advent of sexually transmitted infections and antimicrobial resistance considered as an "emerging global threat" (Cazanave, Manhart, \& Bébéar, 2012; 
Unemo \& Jensen, 2017; Ramalho da CostaLourenço; Barros dos Santos, Meurer Moreira, Longo Fracalanzza, \& Bonelli, 2017), this last question is of a critical importance.

\section{References}

Anscombre, J. C., \& Ducrot, O. (1976). L'argumentation dans la langue [The argumentation in the language]. Langages, 42, 5-27. https:// doi.org/10.3406/lgge.1976.2306

Anscombre, J. C., \& Ducrot, O. (1983). L'argumentation dans la langue [The argumentation in the language]. Brussels, Belgium: Mardaga.

Bar-Tal, Y., Kishon-Rabin, L., \& Tabak, N. (1997). The effect of need and ability to achieve cognitive structuring on cognitive structuring. Journal of Personality and Social Psychology, 73, 1158-1176. https://doi.org/10.1037/0022-3514.73.6.1158

Bassano, D. (1991). Opérateurs et connecteurs argumentatifs: Une approche psycholinguistique [Operators and argumentatives connectors: A psycholinguistic approach]. Intellectica, 11, 149191. https://doi.org/10.3406/intel.1991.1381

Cacioppo, J. T., Petty, R. E., \& Morris, K. (1983). Effects of need for cognition on message evaluation, recall, and persuasion. Journal of Personality and Social Psychology, 45, 805-818. https:// doi.org/10.1037/0022-3514.45.4.805

Cazanave, C., Manhart, L. E., \& Bébéar, C. (2012). Mycoplasma genitalium, an emerging sexually transmitted pathogen. Médecine et Maladies Infectieuses, 42, 381-392. https://doi.org/10.1016/ j.medmal.2012.05.006

Champaud, C., \& Bassano, D. (1987). Argumentative and informative functions of French intensity modifiers "presque", "à peine", and "à peu près": An experimental study on children and adults. Cahiers de Psychologie Cognitive, 7, 605-631.

Cronley, M. L., Posavac, S. S., Meyer, T., Kardes, F. R., Kellaris, J. J. (2005). A selective hypothesis testing perspective on price-quality inference and inference-based choice. Journal of Consumer Psychology, 15, 159-169. https://doi.org/10.1207/ s15327663jcp1502_8

Croskerry, P. (2003). The importance of cognitive errors in diagnosis and strategies to minimize them. Academic Medicine, 78, 775-780. https://doi.org/ 10.1097/00001888-200308000-00003

Dhaliwal, G. (2016). Premature closure? Not so fast. BMJ Quality \& Safety, 26, 87-89. http://dx.doi.org/ 10.1136/bmjqs-2016-005267

Defrise, C., \& Nirenburg, S. (1990). Meaning representation and text planning. In COLING-90: Pro- ceedings of the $13^{\text {th }}$ International Conference on Computational Linguistics (Vol. 3, pp. 219-224). Helsinki, Finland: Association for Computational Linguistics.

Dillard, J. P., \& Shen, L. (2005). On the nature of reactance and its role in persuasive health communication. Communication Monographs, 72, 144-168. https://doi.org/10.1080/ 03637750500111815

Donohew, L., Pugzles Lorch, E., \& Palmgreen, P. (1998). Applications of a theoretic model of information exposure to health interventions. Human Communication Research, 24, 454-468. https:// doi.org/10.1111/j.1468-2958.1998.tb00425.x

Ducrot, O. (1993). Pour une description non-veritative du langage [For a no veritative description of language]. Actes du congrès de linguistique de Séoul, 86-98.

Graber, M. L., Franklin, N., \& Gordon, R. (2005). Diagnostic error in internal medicine. Archives of Internal Medicine, 165, 1493-1499. https://doi.org/ 10.1001/archinte.165.13.1493

Henning, N. (1982). Problems in the semantic-pragmatic description of French adverbials like męme, aussi, surtout and seulement. Acta Hafniensia, 17, 59-71. https://doi.org/10.1080/03740463. 1982.10416045

Houghton, D. C., \& Grewald, R. (2000). Please, let's get an answer - any answer: Need for consumer cognitive closure. Psychology \& Marketing, 17, 911-934. https://doi.org/10.1002/1520-6793 (200011)17:11<911::AID-MAR1>3.0.CO;2-4

Hull, S. J., \& Hong, Y. (2016). Sensation seeking as a moderator of gain and loss framed HIV-test promotion message effects. Journal of Health Communication, 21, 46-55. https://www.tandfonline. com/doi/abs/10.1080/10810730.2015.1033113

Iten, C. (2000). The relevance of argumentation theory. Lingua, 110, 665-699. https://doi.org/ 10.1016/S0024-3841(00)00008-5

Kay, P. (1990). Even. Linguistics and Philosophy, 13, 59-111. https://doi.org/10.1007/BF00630517

Klein, C. T. F., \& Webster, D. M. (2000). Individual differences in argument scrutiny as motivated by need for cognitive closure. Basic and Applied Social Psychology, 22, 119-129. https://doi.org/ 10.1207/15324830051036207

Kossowska, M., \& Bar-Tal, Y. (2013). Need for closure and heuristic information processing: The moderating role of the ability to achieve the need for closure. British Journal of Psychology, 104, 457-480. https://doi.org/10.1111/bjop.12001

Kruglanski, A. W. (1989). Lay epistemics and human knowledge: Cognitive and motivational bases. New York: Plenum. 
Kruglanski, A. W. (1990). Motivations for judging and knowing: Implications for causal attribution. In E. T. Higgins \& R. M. Sorrentino (Eds.), Handbook of motivation and cognition: Foundations of social behavior (Vol. 2, pp. 333-368). New York: Guilford Press.

Kruglanski, A. W. (2004). The psychology of closedmindedness. New York: Psychology Press.

Kruglanski, A. W., \& Ajzen, I. (1983). Bias and error in human judgment. European Journal of Social Psychology, 13, 1-44. https://doi.org/10.1002/ ejsp.2420130102

Kruglanski, A. W., \& Chun, W. Y. (2008). Motivated closed-mindedness and its social consequences. In J. Y. Shah \& W. L. Gardner (Eds.), Handbook of motivation science (pp. 84-99). New York: The Guilford press.

Kruglanski, A. W., \& Fishman, S. (2009). The need for cognitive closure. In M. R. Leary \& R. H. Hoyle (Eds.), Handbook of individual differences in social behavior (pp. 343-353). New York: Guilford Press.

Kruglanski, A. W., \& Freund, T. (1983). The freezing and unfreezing of lay-inferences: Effects on impressional primacy, ethnic stereotyping, and numerical anchoring. Journal of Experimental Social Psychology, 19, 448-468. https://doi.org/ 10.1016/0022-1031(83)90022-7

Kruglanski, A. W., Orehek, E., Dechesne, M., \& Pierro, A. (2010). Lay epistemic theory: The motivational, cognitive, and social aspects of knowledge formation. Social and Personality Psychology Compass, 4, 939-950. https://doi.org/10.1111/j.17519004.2010.00308.x

Kruglanski, A. W., Peri, N., \& Zakai, D. (1991). Interactive effects of need for closure and initial confidence on social information seeking. Social Cognition, 9, 127-148. https://doi.org/10.1521/soco. 1991.9.2.127

Kruglanski, A. W., \& Webster, D. (1996). Motivated closing of the mind: "Seizing" and "freezing". Psychological Review, 103, 263-283. https://doi.org/ 10.1037/0033-295X.103.2.263

Kruglanski, A. W., Webster, D. M., \& Klem, A. (1993). Motivated resistance and openness to persuasion in the presence or absence of prior information. Journal of Personality and Social Psychology, 65, 861-876. https://doi.org/10.1037/00223514.65.5.861

Kunda, Z. (1980). The case for motivated reasoning. Psychological Bulletin, 108, 480-498. https:/ /doi.org/10.1037/0033-2909.108.3.480

Kunda, Z. (1999). Social cognition. Making sense of people. Massachusetts: MIT Press.
Lane, D. D., Harrington, N. G., Donohew, L. \& Zimmerman, R. S. (2006). Dimensions and validation of a Perceived Message Cognition Value Scale. Communication Research Reports, 23, 149-161. https://doi.org/10.1080/08824090600796369

Latimer, A. E., William-Piehota, P., Katulak, N. A., Cox, A., Mowad, L., Higgins, E. T., \& Salovey, P. (2008). Promoting fruit and vegetables intake through messages tailored to individual differences in regulatory focus. Annals of Behavioral Medicine, 35, 363-369. https://doi.org/10.1007/s12160-0089039-6

Lavine, H., \& Snyder, M. (1996). Cognitive processing and the functional matching effect in persuasion: The mediating role of subjective perceptions of message quality. Journal of Experimental Social Psychology, 32, 580-604. https://doi.org/ 10.1006/jesp.1996.0026

Malrieu, J. P. (1999). Evaluative semantics. Cognition, language and ideology. London: Routledge.

Mann, T. L., Sherman, D. K., \& Updegraff, J. A. (2004). Dispositional motivations and message framing: A test of the congruency hypothesis in college students. Health Psychology, 23, 330-334. https:// doi.org/10.1037/0278-6133.23.3.330

McKeown, K. R., \& Elhadad, M. (1991). A contrastive evaluation of functional unification grammar for surface language generation: A case study in choice of connectives. In C. L. Paris, W. R. Swartout, \& W. C. Mann (Eds.), Natural language generation in artificial intelligence and computational linguistics (pp. 351-396). Boston, MA: Springer. https://doi.org/10.1007/978-1-47575945-7_14

Moeschler, J. (2016). Argumentation and connectives. How do discourse connectives constrain argumentation and utterance interpretations. In A. Capone \& J. Mey (Eds.), Interdisciplinary studies in pragmatics, culture, and society (pp. 653-675). Heidelberg: Springer Cham. https://doi.org/10.1007/ 978-3-319-12616-6_26

Molden, D. C., \& Higgins, E. T. (2012). Motivated thinking. In K. J. Holyoak \& R. G. Morisson (Eds.), The Oxford handbook of thinking and reasoning ( $\mathrm{pp}$. 390-412). Oxford: Oxford University Press. https:/ /doi.org/10.1093/oxfordhb/9780199734689. 013.0020

Peltier, J. W., \& Schibrowsky, J. A. (1994). Need for cognition, advertisement viewing time and memory for advertising stimuli. Advances in Consumer Research, 21, 244-250.

Petty, R. E., \& Cacioppo, J. T. (1977). Forewarning, cognitive responding, and resistance to persuasion. Journal of Personality and Social Psychol- 
ogy, 35, 645-655. https://psycnet.apa.org/doi/ 10.1037/0022-3514.35.9.645

Petty, R. E., \& Cacioppo, J. T. (1979). Effects of forewarning of persuasive intent and involvement on cognitive responses and persuasion. Personality and Social Psychological Bulletin, 5, 173-176. https://doi.org/10.1177/014616727900500209

Petty, R. E., \& Cacioppo, J. T. (1986). The Elaboration Likelihood Model of Persuasion. In L. Berkowitz (Ed), Advances in experimental social psychology (pp. 123-205). Orlando, FL: Academic Press. https://doi.org/10.1016/S0065-2601(08)60214-2

Petty, R. E., Haugtvedt, C. P., \& Smith, S. M. (1995). Elaboration as determinant of attitude strength: Creating attitudes that are persistent, resistant and predictive of behavior. In R. E. Petty \& J. A. Krosnick (Eds.), Attitude strength: Antecedents and consequences (pp. 93-130). Hillsdale, NJ: Erlbaum.

Pierro, A., Mannetti, L., Erb, H. P., Spiegel, S., \& Kruglanski, A. W. (2005). Informational length and order of presentation as determinants of persuasion. Journal of Experimental Social Psychology, 41, 458-469. https://doi.org/10.1016/j.jesp. 2004.09.003

Portolés, J., \& Yates, J. (2014). The theory of argumentation within language and its application to discourse analysis. In M. Casado Velarde (Ed.), Language use in public sphere. Methodological perspectives and empirical applications (pp. 201224). Frankfurt am Main: Peter Lang.

Quick, B. L., \& Stephenson, M. T. (2008). Examining the role of trait reactance and sensation seeking on perceived threat, state reactance, and reactance restoration. Human Communication $R e-$ search, 34, 448-476. https://doi.org/10.1111/ j.1468-2958.2008.00328.x

Quintiliani, L. M., \& Carbone, E. T. (2005). Impact of diet-related cancer prevention messages written with cognitive and affective arguments on message characteristics, stage of change and selfefficacy. Journal of Nutrition Education and Behavior, 37, 12-19. https://doi.org/10.1016/S14994046(06)60254-6

Ramalho da Costa-Lourenço, A. P., Barros dos Santos, K. T., Meurer Moreira, B., Longo Fracalanzza, S. E., \& Bonelli, R. R. (2017). Antimicrobial resistance in Neisseria gonorrhoeae: History, molecular mechanisms and epidemiological aspects of an emerging global threat. Brazilian Journal of Microbiology, 48, 617-628. https:// doi.org/10.1016/j.bjm.2017.06.001

Rocci, A. (2017). Modality in argumentation. Dordrecht, The Netherlands: Springer.

Roets, A., \& Van Hiel, A. (2006). Need for closure relations with authoritarianism, conservative be- liefs and racism: The impact of urgency and permanence tendencies. Psychologica Belgica, 46, 235-252. https://doi.org/10.5334/pb-46-3235

Roets, A., \& Van Hiel, A. (2007). Separating ability from need: Clarifying the dimensional structure of the need for closure scale. Personality and Social Psychology Bulletin, 33, 266-280. https:// doi.org/10.1177/0146167206294744

Roets, A., \& Van Hiel, A. (2011a). An integrative process approach on judgment and decision making: The impact of arousal, affect, motivation, and cognitive ability. The Psychological Record, 61, 497520. https://doi.org/10.1007/BF03395773

Roets, A., \& Van Hiel, A. (2011b). Item selection and validation of a brief 15-item version of the need for closure scale. Personality and Individual Differences, 50, 90-94. https://doi.org/10.1016/ j.paid.2010.09.004

Roets, A., Van Hiel, A., \& Cornelis, I. (2006). The dimensional structure of the need for cognitive closure scale: Relationships with "seizing" and "freezing" processes. Social Cognition, 24, 2245. https://doi.org/10.1521/soco.2006.24.1. 22

Sadock, J. M. (1981). Almost. In P. Cole (Ed.), Radical pragmatics (pp. 257-271). New York: Academic press.

Sankaran, S., Szumowska, E., \& Kossowska, M. (2017). "When the going gets tough, the tough get going": Motivation towards closure and effort investment in the performance of cognitive tasks. Motivation and Emotion, 41, 308-321. https:// doi.org/10.1007/s11031-017-9613-y

Strojny, P., Kossowska, M., \& Strojny, A. (2016). When the need for closure promotes complex cognition. Annals of Psychology, 19, 27-42. http:/ /dx.doi.org/10.18290/rpsych.2016.19.1-1en

Trowbridge, R. L. (2008). Twelve tips for teaching avoidance of diagnostic errors. Medical Teacher, 30, 496-500. https://doi.org/10.1080/ 01421590801965137

Unemo, M., \& Jensen, J. S. (2017). Antimicrobialresistant sexually transmitted infections: Gonorrhea and mycoplasma genitalium. Nature Reviews Urology, 14, 139-152. https://doi.org/10.1038/ nrurol.2016.268

Ungar, N., Sieverding, M., Schweizer, F., \& Stadnitski, T. (2015). Intervention-elicited reactance and its implication. Let me eat what I want. Zeitschrift für Psychologie, 223, 247-256. https://doi.org/ 10.1027/2151-2604/a000226

Updegraff, J. A., Sherman, D. K., Luyster, F. S., \& Mann, T. L. (2007). The effects of message quality and congruency on perceptions of tailored 
health communications. Journal of Experimental Social Psychology, 43, 249-257. https://doi.org/ 10.1016/j.jesp.2006.01.007

Van Eemeren, F. H. (2001). Crucial concepts in argumentation theory. Amsterdam: Amsterdam University Press.

Van Eemeren, F. H., Grootendorst, R., \& Snoeck Henkemans, F. (1996). Fundamentals of argumentation theory. A handbook of historical backgrounds and contemporary developments. Mahwah, New Jersey: Lawrence Erlbaum Associates.

Vermeir, I., \& Van Kehnove, P. V. (2005). The influence of need for closure and perceived time pressure on search effort for price and promotional information in a grocery shopping context. Psychology \& Marketing, 22, 71-95. https://doi.org/ 10.1002/mar.20047

Vermeir I., Van Kehnove, P. V., \& Hendrickx, H. (2002). The influence of need for closure on consumers choice behavior. Journal of Economic Psychology, 23, 703-727. https://doi.org/10.1016/S01674870(02)00135-6

Webster, D. M., \& Kruglanski, A. W. (1994). Individual differences in need for cognitive closure. Personality Processes and Individual Differences, 67, 1049-1062. https://doi.org/10.1037/00223514.67.6.1049
Webster, D. M., \& Kruglanski, A. W. (1998). Cognitive and social consequences of the need for cognitive closure. In W. Stroebe \& M. Hewstone (Eds.), European review of social psychology (vol. 8, pp. 133-141). London, UK: John Wiley \& Sons. https:/ /doi.org/10.1080/14792779643000100

Wesson, C. J., \& Pulford, B. (2005). Individuals differences in the influence of confidence: The effects of need for closure and need for cognition [abstract]. Proceedings of the British Psychological Society, 13, 163.

William-Piehota, P., Pizzaro, J., Schneider, T. R., Mowad, L., \& Salovey, P. (2005). Matching health messages to monitor-blunter coping styles to motivate screening mammography. Health Psychology, 24, 58-67. https://doi.org/10.1037/02786133.24.1.58

William-Piehota, P., Schneider, T. R., Pizzaro, J., Mowad, L., \& Salovey, P. (2003). Matching health messages to information-processing styles: Need for cognition and mammography utilization. Health Communication, 15, 375-392. https://doi.org/ 10.1207/S15327027HC1504_01

Wilson, D. (2011). The conceptual - procedural distinction: Past, present and future. In V. EscandellVidal, M. Leonetti, \& A. Ahern (Eds.), Procedural meaning: Problems and perspectives (pp. 3-31). Bingley, UK: Emerald Group Publishing. 